\title{
A new interpretation of the bee fossil Melitta willardi Cockerell (Hymenoptera, Melittidae) based on geometric morphometrics of the wing
}

\author{
Alexandre Dewulf ${ }^{1, \dagger}$, Thibaut De Meulemeester ${ }^{1,2, \neq}$, Manuel Dehon ${ }^{1, \S}$, \\ Michael S. Engel ${ }^{3, \mid}$, Denis Michez ${ }^{1, \pi}$
}

I University of Mons, Research Institute of Biosciences, Laboratory of Zoology, Place du parc 20, 7000 Mons, Belgium 2 Naturalis Biodiversity Center, Darwinweg 2, PoBox 9517, 2300RA Leiden, the Netherlands 3 Division of Entomology (Paleoentomology), Natural History Museum, and Department of Ecology and Evolutionary Biology, 1501 Crestline Drive - Suite 140, University of Kansas, Lawrence, KS 66045, U.S.A.

† http://zoobank.org/38D1ABCA-BBD7-44C7-9ABD-65F2984AD375

† http://zoobank.org/OE4BB69F-69FF-4F34-A9C9-8D078E8A572E

§ http://zoobank.org/5B930FCE-222C-453C-B6CE-E682BA6152E8

| http://zoobank.org/3714A7FF-E19E-495A-AAF9-98D2F597B757

I http://zoobank.org/8B04585A-FE00-4D9A-AFD6-1BD2A1584CFA

Corresponding author: Denis Michez (denis.michez@umons.ac.be)

Academic editor: Jes Rust | Received 18 January 2014 | Accepted 27 February 2014 | Published 14 March 2014

http://zoobank.org/50E869E7-C37C-4BED-BDD2-93CFE29B3443

Citation: Dewulf A, De Meulemeester T, Dehon M, Engel MS, Michez D (2014) A new interpretation of the bee fossil Melitta willardi Cockerell (Hymenoptera, Melittidae) based on geometric morphometrics of the wing. ZooKeys 389 : 35-48. doi: 10.3897/zookeys.389.7076

\begin{abstract}
Although bees are one of the major lineages of pollinators and are today quite diverse, few well-preserved fossils are available from which to establish the tempo of their diversification/extinction since the Early Cretaceous. Here we present a reassessment of the taxonomic affinities of Melitta willardi Cockerell 1909, preserved as a compression fossil from the Florissant shales of Colorado, USA. Based on geometric morphometric wing shape analyses M. willardi cannot be confidently assigned to the genus Melitta Kirby (Anthophila, Melittidae). Instead, the species exhibits phenotypic affinity with the subfamily Andreninae (Anthophila, Andrenidae), but does not appear to belong to any of the known genera therein. Accordingly, we describe a new genus, Andrenopteryx gen. n., based on wing shape as well as additional morphological features and to accommodate M. willardi. The new combination Andrenopteryx willardi (Cockerell) is established.
\end{abstract}

Copyright Alexandre Dewulf et al. This is an open access article distributed under the terms of the Creative Commons Attribution International License (CC BY 4.0), which permits unrestricted use, distribution, and reproduction in any medium, provided the original author and source are credited. 


\section{Keywords}

Bees, compression, Oligocene, wing shape, geometric morphometrics, Tertiary

\section{Introduction}

Bees (Hymenoptera, Apoidea, Anthophila) are a monophyletic group of largely pollenivorous species derived from among the predatory apoid wasps (Engel 2001a, 2011, Michener 2007). This clade probably appeared in the Early Cretaceous ( $\sim 120$ Myr) (Engel 2001a), and concomitant with the diversification of the Eudicots (Michener 1979, Cardinal and Danforth 2013). While intensive work during the last 20 years has clarified many aspects of bee relationships (e.g., Engel 2011, Danforth et al. 2013), establishing the tempo of this radiation continues to be hampered by significant gaps in their fossil record. Hitherto only 191 fossil species of bees have been described (Michez et al. 2012, Engel et al. 2012, Wappler et al. 2012, Engel and Breitkreuz 2013, Engel and Michener 2013, Engel et al. 2013), but the majority of these come from a relatively restricted number of actual deposits. Four main deposits of bee fossils are known: (i) the Eckfeld/Messel shales (47-44 Myr; Wappler and Engel 2003, Wedmann et al. 2009), (ii) the Baltic amber from the middle Eocene (45 Myr; Engel 2001a, 2008, Gonzalez and Engel 2011), (iii) the Florissant shale from the Eocene-Oligocene boundary (34 Myr; Zeuner and Manning 1976, Engel 2001b, 2002, unpubl. data) and (iv) the Dominican amber from the Miocene (20 Myr; Engel et al. 2012, Engel and Breitkreuz 2013). Specimens in amber are typically preserved with enough fidelity to correctly explore diagnostic morphological characters while compressions generally show a restricted subset of such features (Michener 2000, Engel 2001a). Taxonomic attributions of many compression fossils need objective and robust revision with modern procedures, such as geometric morphometrics (Michez et al. 2012, Wappler et al. 2012), and this is particularly true for the diverse paleofauna from Florissant.

The highly fossiliferous shales of Florissant, Colorado have revealed 34 species and 19 genera belonging to several extant bee families: Apidae, Halictidae, Melittidae, Megachilidae, and Andrenidae (Michez et al. 2012). However, the material is often preserved with little or no relief and specimens typically have only the wing venation or limited structures of the legs and thorax discernible, making comparisons with extant clades difficult. Recently we have had the opportunity to re-examine the putative melittine bee from Florissant, Melitta willardi Cockerell 1909 (Figure 1), and to attempt a better understanding of its affinities with extant and other fossil taxa as determined by wing shape analyses.

\section{Material and methods}

\section{Sampling}

Given that $M$. willardi possesses three submarginal cells we sampled specimens from different extant subfamilies with the same arrangement of cells. All available subfamilies 


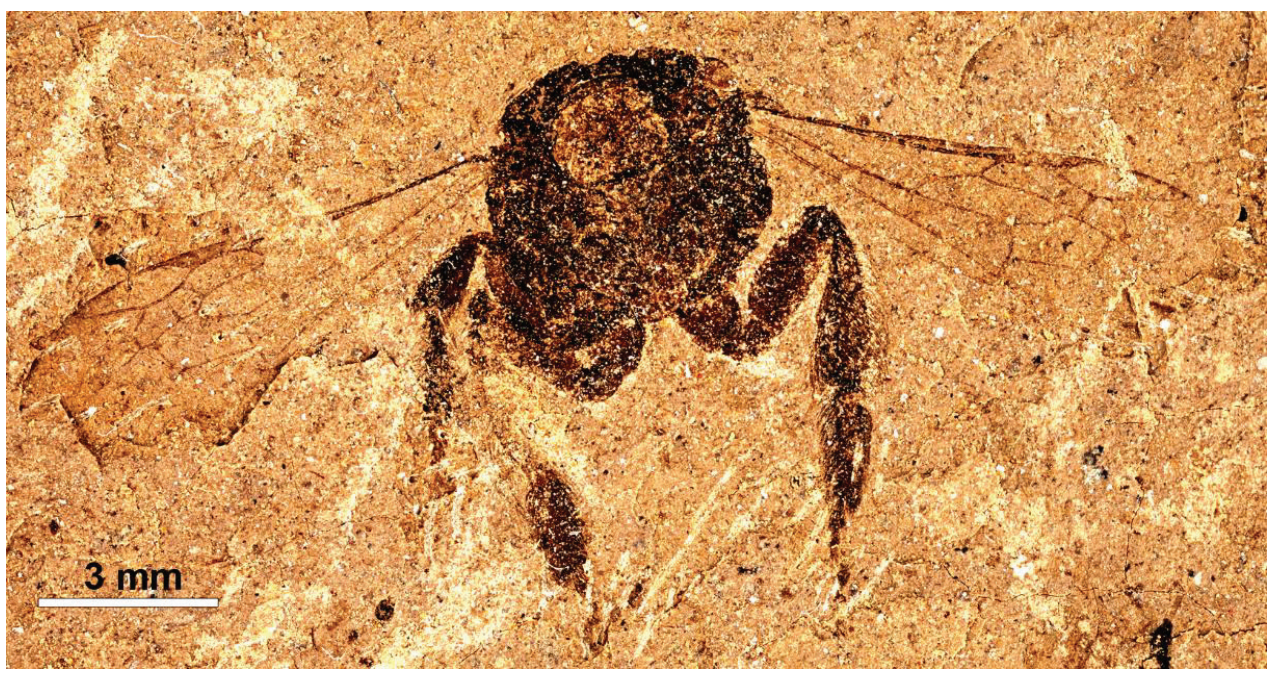

Figure I. Photograph of holotype female of Melitta willardi Cockerell as preserved (UCM 18737). Specimen is preserved facing toward the viewer, with head missing (note the large opening representing the anterior thoracic fossa).

were included, with a maximum of 20 specimens per subfamily, and with a maximum of five specimens per species. We additionally sampled all species of Melitta available with a maximum of five specimens per species. The dataset also included eighteen extinct species [Apidae, Apinae: Anthophorula persephone Engel, 2012; Bombus randeckensis Wappler \& Engel, 2012; Electrapis meliponoïdes (Buttel-Reepen, 1906); E. krishnorum Engel, 2001; Electrobombus samlandensis Engel, 2001; Eufriesea melissiflora (Poinar, 1998); Melikertes stilbonotus (Engel, 2001); Melissites trigona Engel, 2001; Paleohabropoda oudardi Michez \& Rasmont, 2009; Protobombus basilaris Engel, 2001; Probombus hirsutus Piton, 1940; Succinapis goeleti Engel, 2001; and Thaumastobombus andreniformis Engel, 2001; Halictidae, Halictinae: Cyrtapis anomala Cockerell, 1908; Electrolictus antiquus Engel, 2001; Halictus petrefactus Engel \& Peñalver, 2006; Ocymoromelitta sorella Engel, 2002 and O. florissantella (Cockerell, 1906)]. Since the holotype of M. willardi is a female, all individuals used in the morphometric analysis are females to avoid potential bias due to any sexual dimorphism. The assembled dataset comprised 360 specimens representing six families of Anthophila, 15 subfamilies, and 109 species (Table 1).

\section{Morphometric and statistical analyses}

Taxonomic affinities of the fossil were evaluated based on wing shape. Wing venation is used widely in insect taxonomy and can provide many informative features for phylogenetic analyses and for many Late Paleozoic taxa is sometimes the only form of available data (e.g. Gumiel et al. 2003, Pretorius 2005). Moreover, use of the wings has significant advantages compared to other organs, i.e., they are relatively rigid, articulated, 2D struc- 
Table I. Dataset for the geometric morphometric analysis including 360 specimens from 109 species and 15 subfamilies. $\mathrm{N}$ = number of specimens.

\begin{tabular}{|c|c|c|c|}
\hline FAMILY & SUB-FAMILY & SPECIES & $\mathbf{N}$ \\
\hline \multirow{13}{*}{ Andrenidae } & \multirow{4}{*}{ Andreninae } & Andrena bicolor Fabricius, 1775 & 5 \\
\hline & & Andrena boyerella Dours, 1872 & 5 \\
\hline & & Andrena flavipes Panzer, 1799 & 5 \\
\hline & & Andrena fulva (Müller, 1766) & 5 \\
\hline & \multirow{4}{*}{ Oxaeinae } & Oxaea flavescens Klug, 1807 & 1 \\
\hline & & Oxaea fuscescens Sichel, 1865 & 1 \\
\hline & & Oxaea sp. & 1 \\
\hline & & Protoxaea gloriosa (Fox, 1893) & 2 \\
\hline & \multirow{5}{*}{ Panurginae } & Borgatomelissa brevipennis (Walker, 1871) & 1 \\
\hline & & Melitturga clavicornis (Latreille, 1808) & 1 \\
\hline & & Melitturga taurica Friese, 1922 & 5 \\
\hline & & Anthrenoïdes sp. & 2 \\
\hline & & Parapsaenythia puncticutis (Vachal, 1909) & 2 \\
\hline \multirow{25}{*}{ Apidae } & \multirow{17}{*}{ Apinae } & Apis florea Fabricius, 1787 & 5 \\
\hline & & Bombus mendax Gerstäcker, 1869 & 5 \\
\hline & & Melissodes confusa Cresson, 1878 & 5 \\
\hline & & Anthophora plumipes (Pallas, 1772) & 5 \\
\hline & & Paleohabropoda oudardi Michez \& Rasmont, $2009 \dagger$ & 1 \\
\hline & & Anthophorula persephone Engel, $2012 \dagger$ & 1 \\
\hline & & Bombus randeckensis Wappler \& Engel, $2012 \dagger$ & 1 \\
\hline & & Electrapis krishnorum Engel, $2001 \dagger$ & 1 \\
\hline & & Electrapis meliponoides (Buttel-Reepen, 1906) $\dagger$ & 1 \\
\hline & & Electrobombus samlandensis Engel, $2001 \dagger$ & 1 \\
\hline & & Eufriesea melissiflora (Poinar, 1998) $\dagger$ & 1 \\
\hline & & Melikertes stilbonotus (Engel, 2001) $\dagger$ & 1 \\
\hline & & Melissites trigona Engel, $2001 \dagger$ & 1 \\
\hline & & Protobombus basilaris Engel, $2001 \dagger$ & 1 \\
\hline & & Probombus hirsutus Piton, $1940 \dagger$ & 1 \\
\hline & & Succinapis goelet $i$ Engel, $2001 \dagger$ & 1 \\
\hline & & Thaumastobombus andreniformis Engel, $2001 \dagger$ & 2 \\
\hline & \multirow{4}{*}{ Nomadinae } & Epeolus cruciger (Panzer, 1799) & 5 \\
\hline & & Nomada fabriciana (Linnaeus, 1767) & 5 \\
\hline & & Nomada flava Panzer, 1798 & 5 \\
\hline & & Nomada goodeniana (Kirby, 1802) & 5 \\
\hline & \multirow{4}{*}{ Xylocopinae } & Ceratina chloris (Illiger, 1806) & 5 \\
\hline & & Ceratina dallatorreana Friese, 1896 & 5 \\
\hline & & Xylocopa olivieri (Lepeletier de Saint Fargeau, 1841) & 5 \\
\hline & & Xylocopa violacea (Linnaeus, 1758) & 5 \\
\hline \multirow{4}{*}{ Colletidae } & \multirow{4}{*}{ Colletinae } & Colletes cunicularius (Linnaeus, 1761) & 5 \\
\hline & & Colletes daviesanus Smith, 1846 & 5 \\
\hline & & Colletes succinctus (Linnaeus, 1758) & 5 \\
\hline & & Leioproctus sp. & 5 \\
\hline
\end{tabular}




\begin{tabular}{|c|c|c|c|}
\hline FAMILY & SUB-FAMILY & SPECIES & $\mathbf{N}$ \\
\hline & \multirow{8}{*}{ Diphaglossinae } & Cadeguala occidentalis (Haliday, 1836) & 1 \\
\hline & & Caupolicana gayi Spinola, 1851 & 5 \\
\hline & & Caupolicana yarrowi (Cresson, 1875) & 3 \\
\hline & & Crawfordapis luctuosa (Smith, 1861) & 2 \\
\hline & & Diphaglossa gayi Spinola, 1851 & 3 \\
\hline & & Mydrosoma bohartorum Michener, 1986 & 1 \\
\hline & & Ptiloglossa guinnae Roberts, 1971 & 1 \\
\hline & & Ptiloglossa pretiosa (Friese, 1898) & 4 \\
\hline \multirow{24}{*}{ Halictidae } & \multirow{9}{*}{ Halictinae } & Augochlorella striata (Packer, 1990) & 5 \\
\hline & & Halictus ligatus Say, 1837 & 5 \\
\hline & & Ruizantheda nigrocaerulea (Spinola, 1871) & 5 \\
\hline & & Thrinchostoma kandti Blüthgen, 1930 & 5 \\
\hline & & Cyrtapis anomala Cockerell $1908 \dagger$ & 1 \\
\hline & & Electrolictus antiquus Engel $2001 \dagger$ & 1 \\
\hline & & Halictus petrefactus Engel \& Peñalver $2006 \dagger$ & 1 \\
\hline & & Ocymoromelitta florissantella Cockerell $1906 \dagger$ & 1 \\
\hline & & Ocymoromelitta sorella Engel, $2002 \dagger$ & 1 \\
\hline & \multirow{7}{*}{ Nomiinae } & Dieunomia nevadensis (Cresson, 1874) & 1 \\
\hline & & Halictonomia decemmaculata (Friese, 1900) & 2 \\
\hline & & Lipotriches australica (Smith, 1875) & 1 \\
\hline & & Lipotriches modesta (Smith, 1862) & 5 \\
\hline & & Nomia melanderi Cockerell, 1906 & 1 \\
\hline & & Nomia diversipes Latreille, 1806 & 5 \\
\hline & & Pseudapis diversipes (Latreille, 1806) & 5 \\
\hline & \multirow{3}{*}{ Nomioidinae } & Ceylalictus variegatus (Olivier, 1789) & 5 \\
\hline & & Nomioides facilis (Rossi, 1853) & 5 \\
\hline & & Nomioides minutissimus (Rossi, 1790) & 1 \\
\hline & \multirow{5}{*}{ Rophitinae } & Systropha curvicornis (Scopoli, 1770) & 2 \\
\hline & & Systropha maroccana Warncke, 1977 & 3 \\
\hline & & Systropha pici Pérez, 1895 & 2 \\
\hline & & Systropha planidens Giraud, 1861 & 5 \\
\hline & & Systropha sp. & 5 \\
\hline \multirow{4}{*}{ Megachilidae } & \multirow{4}{*}{ Fideliinae } & Fidelia kobrowi Brauns, 1905 & 5 \\
\hline & & Fidelia paradoxa Friese, 1899 & 5 \\
\hline & & Fidelia villosa Brauns, 1902 & 1 \\
\hline & & Fideliopsis major (Friese, 1911) & 2 \\
\hline \multirow{10}{*}{ Melittidae } & \multirow{2}{*}{ Meganomiinae } & Meganomia andersoni (Meade-Waldo, 1916) & 2 \\
\hline & & Meganomia binghami (Cockerell, 1909) & 5 \\
\hline & \multirow{8}{*}{ Melittinae } & Rediviva intermixta (Cockerell, 1934) & 5 \\
\hline & & Rediviva longimanus Michener, 1981 & 3 \\
\hline & & Melitta americana Smith, 1853 & 3 \\
\hline & & Melitta arrogans Smith, 1879 & 5 \\
\hline & & Melitta bicollaris Warncke, 1973 & 5 \\
\hline & & Melitta californica Viereck, 1909 & 1 \\
\hline & & Melitta cameroni (Cockerell, 1910) & 5 \\
\hline & & Melitta dimidiata Morawitz, 1876 & 5 \\
\hline
\end{tabular}




\begin{tabular}{|c|c|c|c|}
\hline FAMILY & SUB-FAMILY & SPECIES & $\mathbf{N}$ \\
\hline & & Melitta eickworti Snelling \& Stage, 1995 & 3 \\
\hline & & Melitta ezoana Yasumatsu \& Hirashima, 1956 & 5 \\
\hline & & Melitta haemorrhoidalis (Fabricius, 1775) & 5 \\
\hline & & Melitta hispanica Friese, 1900 & 5 \\
\hline & & Melitta harrietae (Bingham, 1897) & 5 \\
\hline & & Melitta japonica Yasumatsu \& Hirashima, 1956 & 4 \\
\hline & & Melitta magnifica Michez, 2012 & 3 \\
\hline & & Melitta melittoides (Viereck, 1909) & 2 \\
\hline & & Melitta melanura (Nylander, 1852) & 5 \\
\hline & & Melitta murciana Warncke, 1973 & 5 \\
\hline & & Melitta seitzi Alfken, 1927 & 1 \\
\hline & & Melitta schultzei Friese, 1909 & 1 \\
\hline & & Melitta sibirica (Morawitz, 1888) & 5 \\
\hline & & Melitta aegyptiaca (Radoszkowski, 1891) & 5 \\
\hline & & Melitta leporina (Panzer, 1799) & 5 \\
\hline & & Melitta maura (Pérez, 1896) & 5 \\
\hline & & Melitta nigricans Alfken, 1905 & 5 \\
\hline & & Melitta schmiedeknechti Friese, 1898 & 5 \\
\hline & & Melitta tricincta Kirby, 1802 & 5 \\
\hline & & Melitta avontuurensis Michez \& Kuhlmann, 2014 & 1 \\
\hline & & Melitta richtersveldensis Michez \& Kuhlmann, 2014 & 5 \\
\hline
\end{tabular}

tures that present a large number of useful landmarks formed by the homologous intersections of veins. Geometric morphometrics is a procedure which aims at quantifying and analyzing the overall shape of a structure (Bookstein 1991, Rohlf and Marcus 1993, Adams et al. 2004), and can provide a powerful tool in paleontology for discriminating taxa at different levels as well as for discussing taxonomic affinities between extinct and extant taxa (Roberts 2008, Michez et al. 2009, De Meulemeester et al. 2012, Wappler et al. 2012). The holotype of $M$. willardi does not exhibit any signs of post-mortem tectonic deformation, meaning that the venation observed is reflective of as it was in life and did not require any compensation to adjust for taphonomic or diagenetic alteration.

The right forewings of 360 female specimens were initially photographed using an Olympus SZ010 binocular coupled with a Nikon D70 camera. Photographs were gathered in one TPS file using tps-UTIL 1.56 (Rohlf 2013a). To capture the shape, two dimensional Cartesian coordinates of 18 landmarks (Figure 2) were digitized by tps-DIG 2.17 (Rohlf 2013b). Both right and symmetrized-left wings of M. willardi were digitized by four experimenters $(\mathrm{AD}, \mathrm{MD}, \mathrm{TD}, \mathrm{DM})$ to obtain an objective and robust identification. All landmark configurations were scaled, translated, and rotated against the consensus configuration by the generalized least square Procrustes superimposition method (Bookstein 1991). The superimposition was performed using $\mathrm{R}$ functions of the package "geomorph" (Adams and Otárola-Castillo 2013). The aligned landmark configurations were projected into the Euclidean space tangent to the curved 


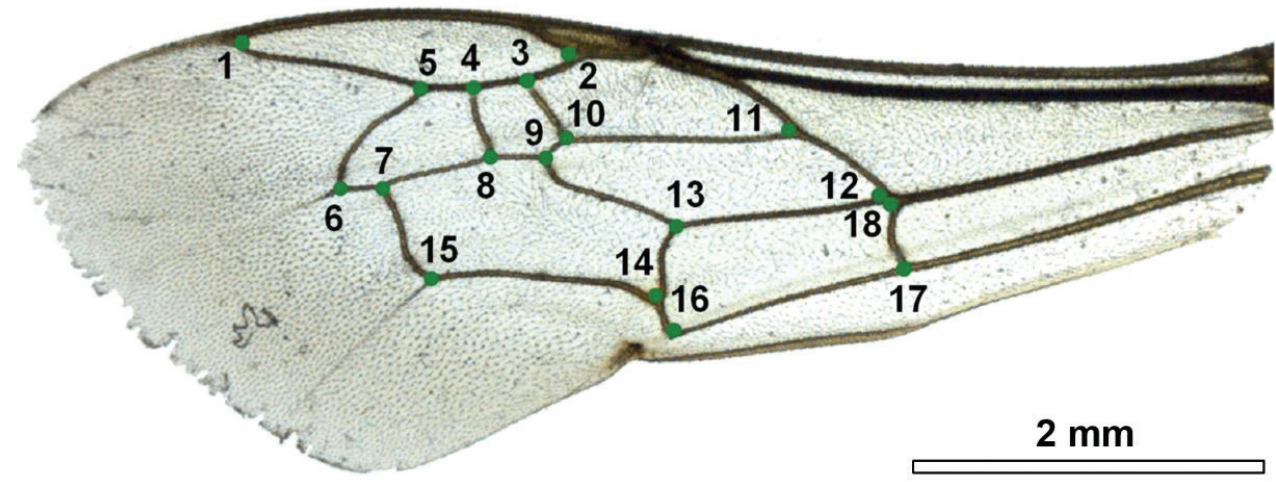

Figure 2. Right forewing of a female of Melitta leporina (Panzer) with the 18 landmarks indicated to describe the shape.

Kendall's shape space to aid further statistical analyses. The closeness of the tangent space to the curved shape space was tested by calculating the least-squares regression slope and the correlation coefficient between the Procrustes distances in the shape space with the Euclidean distances in the tangent space (Rohlf 1999). This variation amplitude of our dataset was calculated with tps-SMALL 1.25 (Rohlf 2013c).

Prior to the assignment of the fossil, shape variation within the reference dataset and discrimination of the different taxa was assessed by Linear Discriminant Analyses (LDA) of the projected aligned configurations of landmarks, with subfamily levels as a priori grouping by using the software $\mathrm{R}$ version 3.0.2 (2013, http://www.R-project. org/). The effectiveness of the LDA for discriminating subfamilies was assessed by the percentages of individuals correctly classified to their original taxon (hit-ratio, HR) in a leave-one-out cross-validation procedure based on the posterior probabilities of assignment. Given the observed scores of an "unknown", the posterior probability (PP) equals the probability of the unit to belong to one group compared to all others. The unit is consequently assigned to the group for which the posterior probability is the highest (Huberty and Olejnik 2006).

Taxonomic affinities of the fossil were assessed based on their score in the predictive discriminant space of shapes. After superimposition of the 368 landmark configurations (i.e. corresponding to the reference dataset and the fossil), aligned coordinates of the 360 specimens from the reference dataset were used to calculate the LDA. We included a posteriori the eight aligned landmark configurations of $M$. willardi in the computed LDA space as "unknown" specimens and calculated their score. Assignments of the fossil configurations were estimated by calculating the Mahalanobis Distance (MD) between "unknowns" and group mean of each subfamily. We also calculated posterior probabilities of assignment to confirm the assignment to one taxon.

In order to assess the taxonomic affinities of $M$. willardi with the family Andrenidae, PCA was computed to visualize shape affinities between the fossil and andrenid subfamilies. 


\section{Results}

\section{Morphometric analysis}

The regression coefficient between the Procrustes distances and the Euclidean distances is close to 1 (0.9999). This means that the linear tangent space closely approximates the shape space, thereby permitting us to be confident in the variation amplitude of our dataset.

In LDA space with subfamily a priori grouping, discrimination of the 15 groups are effective, with a cross-validated HR of $98.61 \%$ (e.g., 5 misclassified specimens), and 10 of the 15 subfamilies that account for a HR of $100 \%$ (Table 2). Other subfamilies have a HR between $90 \%$ and $99 \%$. Due to sampling size within groups, the HR drastically drop down when a single specimen is misclassified. This is the case for the five groups with HR lower than $100 \%$. Cross-validation assignment (Table 2) allows us to be confident in the group discrimination at subfamily level.

All of the 109 specimens of Melitta were correctly classified to their original taxon (Melittinae) in the leave-one-out cross-validation procedure. However, the eight landmark configurations of $M$. willardi are assigned to Andreninae $(\mathrm{MDs}=2.72-4.84$; PPs $=0.9999-1)$. Taxonomic affinities of the fossil were also assessed based on nonsupervised analyses within Andrenidae. In the morphometric space defined by the PCA, the fossil is undoubtedly clustered with the subfamily Andreninae (Figure 3).

\section{Systematic palaeontology}

\section{Family: Andrenidae Latreille, 1802 \\ Subfamily: Andreninae Latreille, 1802}

\section{Genus Andrenopteryx Dewulf \& Engel, gen. $\mathrm{n}$.} http://zoobank.org/2A2AF004-6EEB-47DE-B13F-B91378CF3557 http://species-id.net/wiki/Andrenopteryx

Type species. Melitta willardi Cockerell, 1909.

Included species. The genus presently includes only the type species, Andrenopteryx willardi (Cockerel, 1909), comb. n.

Diagnosis. + : Forewing with three submarginal cells, first submarginal cell largest, second smallest; r-rs long, about as long as anterior border of second submarginal cell; anterior border of second submarginal cell not dramatically shorter than that of third submarginal cell; $1 \mathrm{rs}-\mathrm{m}$ relatively straight; $2 \mathrm{rs}-\mathrm{m}$ greatly arched apical in posterior half; $1 \mathrm{~m}-\mathrm{cu}$ entering second submarginal cell near midpoint; $2 \mathrm{~m}$-cu entering third marginal cell at apical third of cell length, $2 \mathrm{~m}$-cu relatively straight; pterostigma linear, much longer than wide, border inside marginal cell relatively straight; marginal cell with acutely rounded apex, not truncate or appendiculate, apex on costal margin, apical most abscissa Rs relatively straight such that marginal cell apex tapers gradually 
Table 2. Cross-validation assignment in LDA space with subfamily a priori grouping (original groups are along the rows, predicted groups are along the columns). HR = Hit ratio.

\begin{tabular}{|c|c|c|c|c|c|c|c|c|c|c|c|c|c|c|c|c|}
\hline & 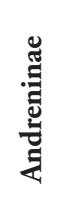 & 总 & $\frac{\tilde{\Xi}}{\stackrel{\Xi}{0}}$ & 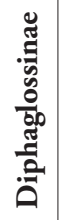 & 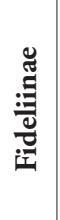 & 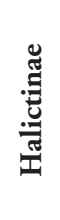 & 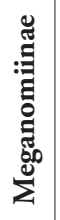 & 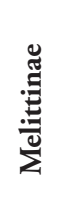 & 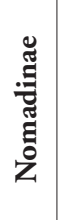 & $\begin{array}{l}\stackrel{\mathscr{Z}}{:} \\
\text { Z } \\
\text { Z }\end{array}$ & 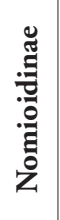 & 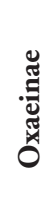 & 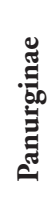 & 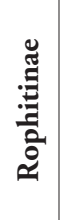 & 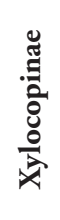 & $\begin{array}{l}\text { HR } \\
(\%)\end{array}$ \\
\hline Andren & 20 & - & - & - & - & - & - & - & - & - & - & - & - & - & - & 100 \\
\hline Apinae & - & 33 & - & 1 & - & - & - & - & - & - & - & - & - & - & - & 97 \\
\hline Colletinae & - & - & 20 & - & - & - & - & - & - & - & - & - & - & - & - & 100 \\
\hline Diphaglossir & - & 1 & - & 19 & - & - & - & - & - & - & - & - & - & - & - & 95 \\
\hline & - & - & - & - & 13 & - & - & - & - & - & - & - & - & - & - & 100 \\
\hline Halict & - & 1 & - & - & - & 24 & - & - & - & - & - & - & - & - & - & 96 \\
\hline Meganomiin & - & - & - & - & - & - & 7 & - & - & - & - & - & - & - & - & 100 \\
\hline Melittinae & - & - & - & - & - & - & - & 117 & - & - & - & - & - & - & - & 100 \\
\hline Noma & - & - & - & - & - & - & - & - & 20 & - & - & - & - & - & - & 100 \\
\hline Nomiinae & - & - & - & - & - & - & - & - & - & 20 & - & - & - & - & - & 100 \\
\hline Nomioidinae & - & - & - & - & - & - & - & - & - & - & 11 & - & - & - & - & 100 \\
\hline Oxaeinae & - & - & - & - & - & - & - & - & - & - & - & 5 & - & - & - & 100 \\
\hline Panurginae & 1 & - & - & - & - & - & - & - & - & - & - & - & 10 & - & - & 91 \\
\hline Rophitinae & - & - & - & - & - & 1 & - & - & - & - & - & - & - & 16 & - & 94 \\
\hline Xylocopinae & - & - & - & - & - & - & - & - & - & - & - & - & - & - & 20 & 100 \\
\hline
\end{tabular}

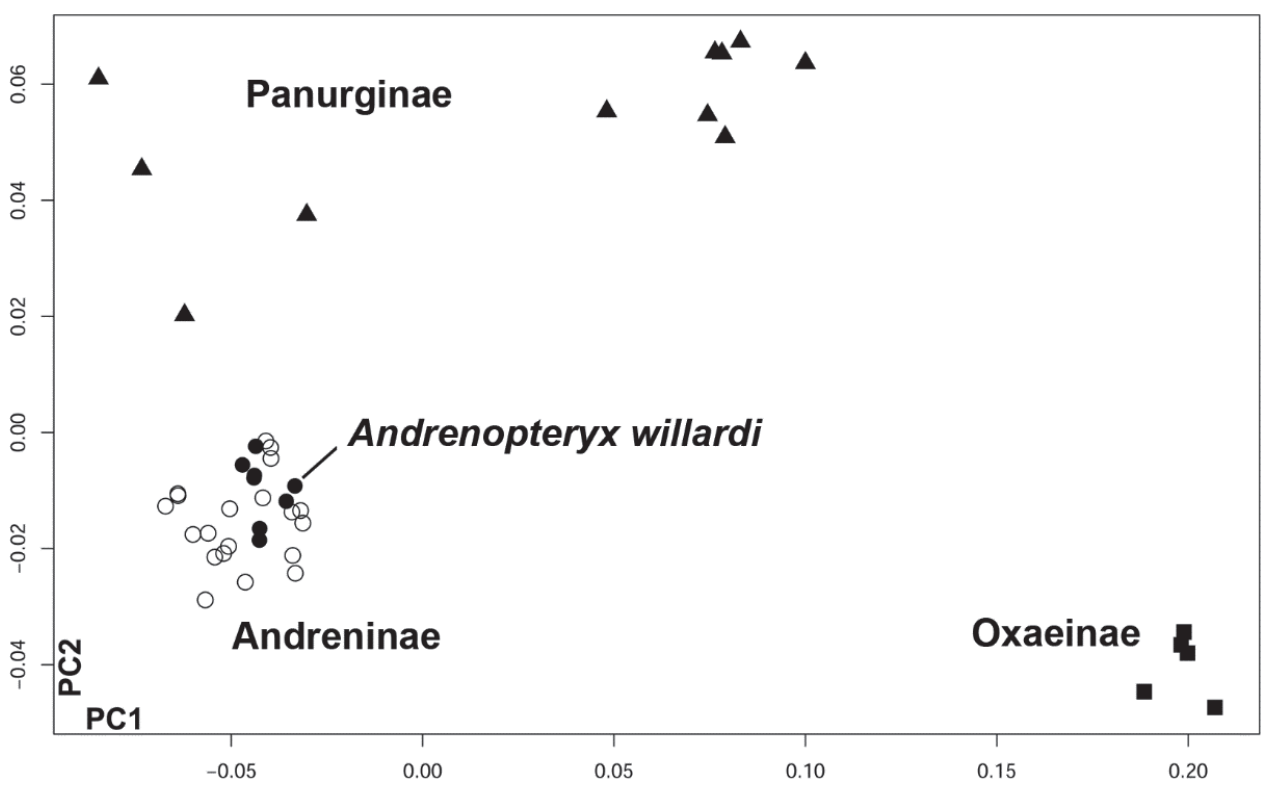

Figure 3. Distribution of extant examined andrenid (36 specimens) and the eight landmark configurations of Andrenopteryx willardi (*), along the first two PC axis (PC1=72\%, PC2=11\%). 
in width from 2rs-m to apex. Pilosity well developed; flocculus absent; scopa present on metafemur and metabasitarsus; metabasitarsus more than half as long as metatibia; pretarsal claws with minute inner tooth. 0 : Unknown.

Etymology. The new genus-group name is a combination of Andrena, type genus of the subfamily Andreninae, and -pteryx, meaning "wing". The name is feminine and refers to the "Andrena-like" venation of the wings.

\section{Discussion}

\section{Position of Andrenopteryx gen. n. in Anthophila}

The wings of Andrenopteryx gen. $\mathrm{n}$. have three submarginal cells, suggesting that the genus does not probably belong to subfamilies such as Xeromelissinae, Hylaeinae, Euryglossinae (all Colletidae), Dasypodainae (Melittidae), Megachilinae (Megachilidae), or various tribes among the Apidae (i.e., Allodapini, Ammobatini, Ammobatoidini, Biastini, Boreallodapini, Caenoprosopidini, Ctenoplectrini, Neolarrini, and Townsendiellini). Furthermore, Andrenopteryx gen. n. clearly possesses pollen-collecting structures, suggesting that the fossil was probably not cleptoparasitic and accordingly those genera may also be excluded (cleptoparasitic genera occur in various families, see Michener 2007). The GM analysis of the wing shape of Andrenopteryx gen. n. suggests that this fossil belongs to the Andrenidae (see previous results, vide supra). Nevertheless, diagnostic features of Andrenidae such as the two subantennal sulci and the short to long pointed glossa are not preserved in the only available specimen of the species.

Assuming that its clustering among Andrenidae is an accurate reflection of its relationships, among andrenids the three submarginals cells excludes placement among most of the Panurginae. The species has a long marginal cell with an acutely curved apex that lies along the costal margin as in Andreninae, while the other subfamilies have a marginal cell with a truncate apex (Michener 2007). The holotype clearly possesses a scopa which is limited to the metafemur and metabasitarsus and without a flocculus, unlike the diverse extant genus Andrena Fabricius. The metabasitarsus is more than half as long as the metatibia, in stark contrast to the form present in Megandrena Cockerell. Lastly, Andrenopteryx gen. $\mathrm{n}$. does not have an enlarged inner tooth on the pretarsal claws, and therefore is distinct from the southern South American genus Orphana Vachal. Thus, while Cockerell's species certainly is best placed in the Andreninae it seems generically distinct and this has served as the basis for our decision to describe a new genus.

\section{Geometric morphometrics of wing shape and Andrenopteryx willardi}

Wing shape analyses were successfully employed in previous studies to discriminate extant bee taxa at various classificatory levels, from subspecies to tribes (e.g., Kandemir et al. 2011, De Meulemeester et al. 2012). In addition, these analyses are sufficient 
to confidently associate bee fossils with extant groups (e.g., Michez et al. 2009, De Meulemeester et al. 2012, Wappler et al. 2012), and this lends increased confidence to the affinities of $A$. willardi as outlined above.

Cockerell (1909) mentioned some features that for him indicated that his fossil species was referable to Melitta. He noted the three submarginal cells, the particular form of the pterostigma, the scopa confined to the metafemur and metabasitarsus, and the absence of a flocculus. However, a majority of these similarities are unfounded and not indicative of Melitta, and in fact some are more suggestive of Andreninae. First, the proportions of the submarginal cells are more similar to Andrenidae than any melittid. Second, the second submarginal cell does not receive the $1 \mathrm{~m}-\mathrm{cu}$ well before its midpoint, and this is true for both the left and right forewings. Thus, even based on the evidence available to Cockerell and from his description the fossil should not be placed within Melitta, and it is peculiar to us why he made such a taxonomic decision.

Based on the discovery that Cockerell's fossil Melitta is more likely an andrenine, some previous hypotheses regarding the biogeography of North American bees require reconsideration. Michez and Eardley (2007) speculated the presence of Melitta in North America during the Oligocene based on Cockerell's (1909) assertion of the taxonomic identity of $A$. willardi, and Dellicour et al. (2014) demonstrated that North American species of Melitta form a derived clade within the genus. There is now no evidence for Michez and Eardley's scenario. The origin of Melitta could be more recent than previously hypothesized and Dellicour et al.'s North American clade could have entered and diversified on the continent during the Neogene. In contrast, the record of Andreninae in North America during the Oligocene is now corroborated by the present fossil. There are additional records of putative andrenines from Florissant, such as Lithandrena saxorum Cockerell, 1906, Pelandrena reducta Cockerell 1909, and five additional species Cockerell placed in Andrena (Michez et al. 2012), but these are in need of re-evaluation. It is hoped that these species may also be subjected to morphometric analyses and their relationships clarified.

\section{The importance of the Florissant shales}

The bees of the Florissant shale have been ignored for a long time (Engel 2002). It was Cockerell's intention to document the whole fossil fauna and flora from Colorado and this partly drove his efforts to document the known bee remains from these deposits (Cockerell 1927, Engel 2002). Cockerell, who largely relied on a hand lens to study specimens, often based his hypotheses regarding the placement of particular fossils on the their general habitus, or relied on a suite of traits recognized nowadays as not indicative of those same families, subfamilies, and even genera. For example, many of the traits concerning wing shape such as the relative positions of the rs-m or $\mathrm{m}-\mathrm{cu}$ crossveins are quite variable within individual families. Subsequent to Cockerell, Zeuner and Manning (1976) tried to evaluate the Florissant fossil bees, but they based their work solely from Cockerell's original descriptions and did not examine type material. Zeuner and Manning's monograph is further compromised 
by the fact that both authors died before the work was completed, leaving behind only notes that were subsequently cobbled together to form the publication, and this explains its poor quality and limited utility (Engel 2002). The only other works were brief accounts by Engel $(2001$ b, 2002), who attempted to re-evaluate Cockerell's Florissant halictines as well as newly discovered material, and to describe a new large carpenter bee. Outside of this, the Florissant fossil bee fauna has remained dormant and given that it is one of the most diverse and specimen-rich deposits for the Anthophila, it is all the more imperative that its species be properly evaluated in a modern context. We hope that this brief treatment of one such species will inspire more investigations into the fossil bees from Colorado.

\section{Acknowledgments}

We sincerely thank the University of Colorado Museum of Natural History (Boulder, USA) and Dena Smith and Talia Karim for making it possible to study Cockerell's holotype of Andrenopteryx willardi. We are grateful to the following curators for collection access within their respective institutions: David Notton, National History Museum (London, UK), Frederique Bakker, Naturalis Biodiversity Center (Leiden, NL), Jeannine Bortels, University of Liège (Gembloux, BE), Eliane De Coninck, Royal Museum of Central Africa (Tervuren, BE), and Wouter Dekoninck, Royal Belgian Institute of Natural Sciences (Bruxelles, BE).

\section{References}

Adams DC, RohlfFJ, Slice DE (2004) Geometric morphometrics: ten years of progress following the 'revolution'. Italian Journal of Zoology 71: 5-16. doi: 10.1080/11250000409356545

Adams DC, Otárola-Castillo E (2013) Geomorph: An R package for the collection and analysis of geometric morphometric shape data. Methods in Ecology and Evolution 4(4): 393-399. doi: 10.1111/2041-210X.12035

Bookstein FL (1991) Morphometric tools for landmark data: Geometry and biology. Cambridge University Press, Cambridge, 435.

Cardinal S, Danforth BN (2013) Bees diversified in the age of eudicots. Proceedings of the Royal Society B-Biological Sciences 280(1755): 1-9.

Cockerell TDA (1909) New North American bees. The Canadian Entomologist 41: 393-395. doi: 10.4039/Ent41393-11

Cockerell TDA (1927) Zoology of Colorado. University Colorado, Denver, 262 pp.

Danforth BN, Cardinal S, Praz C, Almeida EAB, Michez D (2013) The impact of molecular data on our understanding of bee phylogeny and evolution. Annual Review of Entomology 58: 57-78. doi: 10.1146/annurev-ento-120811-153633

De Meulemeester T, Michez D, Aytekin AM, Danforth BN (2012) Taxonomic affinity of halictid bee fossils (Hymenoptera: Anthophila) based on geometric morphomet- 
rics analyses of wing shape. Journal of Systematic Palaeontology 10(4): 755-764. doi: $10.1080 / 14772019.2011 .628701$

Dellicour S, Lecocq T, Kuhlmann M, Mardulyn P, Michez D (2014) Molecular phylogeny, biogeography, and host plant shifts in the bee genus Melitta (Hymenoptera: Anthophila). Molecular Phylogenetics and Evolution 70: 412-419. doi: 10.1016/j.ympev.2013.08.013 Engel MS (2001a) A monograph of the Baltic Amber bees and evolution of the Apoidea (Hymenoptera). Bulletin of the American Museum of Natural History 259: 1-192. doi: 10.1206/0003-0090(2001)259<0001:AMOTBA>2.0.CO;2

Engel MS (2001b) The first large carpenter bee from the Tertiary of North America, with a consideration of the geological history of Xylocopinae (Hymenoptera: Apidae). Transactions of the American Entomological Society 127(2): 245-254.

Engel MS (2002) Halictine bees from the Eocene-Oligocene boundary of Florissant, Colorado (Hymenoptera: Halictidae). Neues Jahrbuch für Geologie und Paläontologie, Abhandlungen 225(2): 251-273.

Engel MS (2008) A new species of Ctenoplectrella in baltic amber (Hymenoptera: Megachilidae). Acta Zoologica Academiae Scientiarum Hungaricae 54(4): 319-324.

Engel MS (2011) Systematic melittology: where to from here? Systematic Entomology 36: 2-15. doi: $10.1111 / j .1365-3113.2010 .00544 . x$

Engel MS, Michener CD (2013) A minute stingless bee in Eocene Fushan amber from northeastern China (Hymenoptera: Apidae). Journal of Melittology 14: 1-10.

Engel MS, Ortega-Blanco J, Nascimbene PC, Singh H (2013) The bees of Early Eocene Cambay amber (Hymenoptera: Apidae). Journal of Melittology 25: 1-12.

Engel MS, Breitkreuz LCV (2013) A male of the bee genus Agapostemon in Dominican amber (Hymenoptera: Halictidae). Journal of Melittology 16: 1-9.

Gonzalez VH, Engel MS (2011) A new species of the bee genus Ctenoplectrella in middle Eocene Baltic amber (Hymenoptera, Megachilidae). Zookeys 111: 41-49. doi: 10.3897/ zookeys.111.1593

Gumiel M, Catala S, Noireau F, Rojas de Arias A, Garcia A, Dujardin JP (2003) Wing geometry in Triatoma infestans (Klug) and T. melanosoma Martinez, Olmedo \& Carcavallo (Hemiptera : Reduviidae). Systematic Entomology 28(2): 173-179. doi: 10.1046/j.13653113.2003.00206.x

Huberty CJ, Olejnik S (2006) Applied MANOVA and Discriminant Analysis. Second Edition. New Jersey, 488 pp. doi: 10.1002/047178947X

Kandemir I, Ö-zkan A, Fuchs S (2011) Reevaluation of honeybee (Apis mellifera) microtaxonomy: A geometric morphometric approach. Apidologie 42(5): 618-627. doi: 10.1007/ s13592-011-0063-3

Michener CD (1979) Biogeography of the bees. Annals of the Missouri Botanical Garden 66: 277-342.

Michener CD, Poinar G (1996) The known bee fauna of the Dominican amber. Journal of the Kansas Entomological Society 69(4): 353-361.

Michener CD (2000) The bees of the world. The Johns Hopkins University Press, Baltimore, xiv+[i]+913 pp., + 16 pls. 
Michener CD (2007) The bees of the world, second edition. The Johns Hopkins University Press, Baltimore, xvi+[i]+953 pp., +20 pls. doi: 10.1080/00379271.2007.10697535

Michez D, Eardley C (2007) Monographic revision of the bee genus Melitta Kirby 1802 (Hymenoptera: Apoidea: Melittidae). Annales de la Société entomologique de France 43 (4): 379-440. doi: 10.2307/2398833

Michez D, De Meulemeester T, Nel A, Rasmont P, Patiny S (2009) New fossil evidence of the early diversification of bees: Paleohabropoda oudardi from the French Paleocene (Hymenoptera, Apidae, Anthophorini). Zoologica Scripta 38(2): 171-181. doi: 10.1111/j.14636409.2008.00362.x

Michez D, Vanderplanck M, Engel MS (2012) Fossil bees and their plant associates. In: Patiny S (Ed) Evolution of plant-pollinator relationships. Cambridge University Press, Cambridge, $103-164$.

Pretorius E (2005) Using geometric morphometrics to investigate wing dimorphism in males and females of Hymenoptera - a case study based on the genus Tachysphex Kohl (Hymenoptera: Sphecidae: Larrinae). Australian Journal of Entomology 44: 113-121. doi: 10.1111/j.1440-6055.2005.00464.x

R Development Core Team (2013) A language and environment for statistical computing, version 3.0.2, ISBN 3-900051-07-0, R Foundation for Statistical Computing. Vienna, Austria.

Roberts DW (2008) Statistical analysis of multidimensional fuzzy set ordinations. Ecology 89 (5): 1246-1260. doi: 10.1890/07-0136.1

Rohlf FJ, Marcus LF (1993) A revolution in Morphometrics. Trends in Ecology \& Evolution 8(4): 129-132. doi: 10.1016/0169-5347(93)90024-J

Rohlf FJ (1999) Shape Statistics: Procrustes Superimpositions and Tangent Spaces. Journal of Classification 16: 197-223. doi: 10.1007/s003579900054

Rohlf FJ (2013a) tpsUTIL Version 1.56. Department of Ecology and Evolution, State University of New York at Stony Brook, New-York.

Rohlf FJ (2013b) tpsDIG Version 2.17. Department of Ecology and Evolution, State University of New York at Stony Brook, New-York.

Rohlf FJ (2013c) tpsSMALL Version 1.25. Department of Ecology and Evolution, State University of New York at Stony Brook, New-York.

Wappler T, Engel MS (2003) The middle Eocene bee faunas of Eckfeld and Messel, Germany (Hymenoptera: Apoidea). Journal of Paleontology 77(5): 908-921. doi: 10.1666/0022-3360(2003)077<0908:TMEBFO>2.0.CO;2

Wappler T, De Meulemeester T, Aytekin AM, Michez D, Engel MS (2012) Geometric morphometric analysis of a new Miocene bumble bee from the Randeck Maar of southwestern Germany (Hymenoptera: Apidae). Systematic Entomology 37(4): 784-792. doi: 10.1111/j.1365-3113.2012.00642.x

Wedmann S, Wappler T, Engel MS (2009) Direct and indirect fossil records of megachilid bees from the Paleogene of Central Europe (Hymenoptera: Megachilidae). Naturwissenschaften 96(6): 703-712. doi: 10.1007/s00114-009-0525-x

Zeuner FE, Manning FJ (1976) A monograph on fossil bees (Hymenoptera: Apoidea). Bulletin of the British Museum (Natural History), Geology 27(3): 149-268. 